\title{
Cultural Revival and the Persistence of Identity in Moldova: from the Folkloric Movement to Hospitality Jennifer R. CASH (Germany)
}

\begin{abstract}
For nearly three-quarters of a century, anthropologists, alongside folklorists, sociologists, and others have steadily documented multiple processes of cultural revival and revitalization, amassing a rich body of evidence to testify to the flexibility and resilience of culture. This focus on successful revivals has generated a wide literature that parallels and supports the growing attention to identity and ethnicity as key concerns across the social sciences. In the following pages, I refer to this literature as I examine the limits of cultural revival in the post-Soviet Republic of Moldova, primarily the country's folkloric movement, which is the subject of my doctoral research and first book. In this broader field of vision, there are questions to be asked: who is undertaking revival work? What are their goals? What are their methods? And - whether they succeed or fail - what are the conditions that enable this? Although I pose these questions in specific reference to post-Soviet Moldova, they could be asked of many communities, to advance our understanding of how collective identities are established, negotiated, and changed over time.
\end{abstract}

Key words: Republic of Moldova, identity, cultural revival

\section{Introduction}

The problem I pose in this article is this: how should we assess the health and vitality of culture in the Republic of Moldova of the early 2000s? There are many indications that efforts to encourage cultural revival in Moldova from the 1980 s to the present have "failed". Persistent underfunding of cultural institutions and limited support for professional workers in the arts and culture is an indicator of weak political support for local cultural life. But, a quick review of academic journals in Moldova during the early 2000s (not to mention conferences, workshops, and informal conversations) reveals a persistent concern among ethnographers and sociologists (among others) that Moldova's citizens were abandoning key elements of past cultural practices, and might be in danger of losing ethnic identities without having adopted new identities of equivalent cultural richness. Certainly the leaders and key members of the folkloric movement whom I interviewed in the early and mid-2000s reported that their efforts in cultural revival had failed. My question in this essay is how we should interpret such assessments of failure. Other than lack of identity or concern for cultural traditions, what does the "failure" of cultural revival reveal? 
Can cultural identity thrive even if revival fails? My analysis concentrates primarily on the country's folkloric movement, which became the subject of my doctoral research and first book, ${ }^{1}$ but extends to consider findings from my subsequent research, particularly that undertaken as a member of the "Economy and Ritual Group” at the Max Planck Institute for Social Anthropology during the period 2009-2011.

\section{Revival, Revitalization, and (Re)Invention: Which Terms to Use?} My assessment begins with a brief consideration of how we might understand Moldova's folkloric movement as an example of a widespread effort at cultural revival that failed. First comes a consideration of terminology, and of how the movement can be classified within the scientific literature on revivals.

In the 1980s, a folkloric movement appeared in the Republic of Moldova. Folk singers and musicians performed during public political meetings, drawing tears from their audiences. Numerous folk festivals and competitions were organized for amateur performers, and the juries encouraged these groups to make their costumes and repertoires increasingly more authentic. In a span of twenty years, folkloric performance became widespread and highly visible. By 2001, when I conducted the majority of my field research on the movement, there were as many as 2,000 amateur folk ensembles, and new festivals continued to be initiated to showcase and develop folklore. Folk music and dance were regularly visible in television and radio broadcasts; free outdoor concerts were scheduled on public holidays; and folk performers were hired by restaurants, as well as private birthday and wedding celebrations. Yet even as folklore flourished, members of the folkloric movement reported that they had failed to generate the broader cultural revival that they had once hoped to create. Before examining the work of this movement, and the contours of the revival its participants had imagined, let us turn to a consideration of the terminology we might use: revival, revitalization, (re)invention.

1 Jennifer R. Cash, Villages on Stage: Folklore and Nationalism in the Republic of Moldova. Berlin: LIT Verlag, 2011.

2 Fieldwork was undertaken in 2001 as an Individual Advanced Research Opportunity (IARO) funded by the International Research and Exchanges Board (IREX); in 2005 with the support of the National Council for Eurasian and East European Research (NCEEER); in 2005 and 2006 with a grant for Collaborative Research from the National Endowment for the Humanities (NEH) administered through ACCTR. In 2009-2010, I conducted field research as a member of the "Economy and Ritual" group at the Max Planck Institute for Social Anthropology. I am grateful for the generous support of each of these institutions. I alone remain responsible, however, for the views expressed here. 
Leaders of Moldova's folkloric movement (mişcarea folclorică) frequently describe their work as related to national rebirth (renaşterea națională). Such a phrasing, when approached scientifically, belongs more to the political domain than to that of public culture. I therefore searched for other terms that would allow analysis of the movement in the cultural domain. Revival, revitalization, and the (re)invention of tradition, are three such terms that might be applied to understand the movement ethnographically and sociologically.

For more than two decades now, the "invention of tradition" has largely replaced the earlier concepts of revival and revitalization, without adequate explanation despite obvious similarities. ${ }^{3}$ The appeal of the newer concept is linked both to the greater engagement between anthropology and history, ${ }^{4}$ and to waning interest in the "universal models of human behavior," which revitalization studies initially represented. "Invented traditions" call attention to the power dynamics involved in creating culture, particularly the state's interest in tradition, and more broadly to the creative power of individuals and communities to generate culture anew. Critics, however, point to the rupture that the concept creates between scholarly agendas and local "inventors," who - in many cases, are the same kinds of indigenous activists that anthropologists tend to support. ${ }^{6}$

This is one of the reasons that the "invention of tradition" suits the present analysis poorly. In dividing external analysts from local activists, the local activists suffer twice in the sphere of public intellectual activity - first because their activities can be delegitimized as "inventions," and secondly, because they lack rhetorical devices other than those of rebirth, revival, or revitalization to achieve goals within cultural domains. ${ }^{7}$ It is perhaps for this reason that anthropological linguists, who often work in tandem with local

3 Joel Robbins, "Whatever Happened to Revival? From Charismatic Movement to Charismatic Church in a Papua New Guinea Society." Journal of Ritual Studies. 2001, 15(2): 79-90. Ann McMullen, "Canny about Conflict": Nativism, Revitalization, and the Invention of Tradition in Native Southeastern New England. In: Michael Harkin, ed. Reassessing Revitalization Movements: Perspectives from North America and the Pacific Islands. Lincoln and London: University of Nebraska Press, 2004, 261-278.

4 John D. Kelly, Martha Kaplan, "History, Structure, and Ritual." Annual Review of Anthropology, 1990, 19: 119-150.

5 Matthew Liebmann, “The Innovative Materiality of Revitalization Movements: Lessons from the Pueblo Revolt of 1680." American Anthropologist, 2008, 10(3): 360-372.

6 Jonathan Friedman, “The Past in the Future: History and the Politics of Identity." American Anthropologist, 1992, 94:837-859; Haunani-Kay Trask, "Natives and Anthropologists: The Colonial Struggle." Contemporary Pacific, 1991, 3:159-177.

7 Charles Briggs, "The Politics of Discursive Authority in Research on the "Invention of Tradition." Cultural Anthropology, 1996, 11(4): 435-469. 
language activists, continue to refer to language "revitalization," rather than "reinvention," even as they recognize that the connections between language, community, and identity shift with revitalization projects. ${ }^{8}$

Although I have used the concept of invention in some other publications, removing it here also allows me to bring the topics of revival and revitalization into closer dialogue with each other. Although revival and revitalization have continued to appear as frequent topical interests in anthropological research, their theorization has been relatively weak during the ascent of "invention." The two terms, "revival" and "revitalization" have slightly different pedigrees, but authors who explicitly define both usually minimize the differences between them, often even equating them with invention, and a host of other similar concepts. ${ }^{9}$ There are good reasons to make this assimilation - for example, to emphasize the multiplicity of forms through which culture is continually renewed - but such a move also avoids exploring the barriers to adequate comparative research that inattention to terminological distinctions and relations can generate. ${ }^{10}$

Bracketing the issue of invention allows a more explicit dialogue between anthropology and folklore (rather than anthropology and history), which is especially relevant in this particular case study. It also calls attention to the need for further discussion about the relation between revival and revitalization. Both terms are widely used, but often undefined and untheorized. As discussed below, each term is also preferentially used by particular disciplines, for particular world areas, and to address particular topics. Harkin ${ }^{11}$ reveals the acuteness of this problem with respect to the term "revitalization," demonstrating that it could be - but is not - applied to a wide variety of political and religious movements in Europe, Africa, and non-native North America, including folklorically-inspired nationalist movements.

Of the two terms, "revival," even when appearing as "cultural revival," has had a broader circulation as a shared topic of interest across several disciplines. "Cultural revival" refers, with nearly equal frequency in bibliographic searches, to revivals of literary genres, increased energy in mainstream religious

8 Sam L. No'eau Warner, Kuleana: “The Right, Responsibility, and Authority of Indigenous Peoples to Speak and Make Decisions for Themselves in Language and Cultural Revitalization." Anthropology \& Education Quarterly, 1999, 30(1): 68-93; Laiana Wong, "Authenticity and the Revitalization of Hawaiian.” Anthropology \& Education Quarterly, 1999, 30(1): 94-115.

9 E.g. Jeremy Boissevain ed., Revitalizing European Rituals. London: Routledge. Boyes, Georgina; Owe Ronstrom (1996). Revival Reconsidered. World of Music, 1992, 38(3): 5-20.

10 Ann McMullen, “Canny about Conflict” ..., 261-278.

11 Michael Harkin, ed. Reassessing Revitalization Movements: Perspectives from North America and the Pacific Islands. Lincoln and London: University of Nebraska Press, 2004, xviii-xx. 
traditions, and the strengthening of cultural, political, and social identities among ethnic minorities and indigenous peoples. The common appeal of "revival" across disciplines resides in the term's implied metaphor of death or near-death, which is overcome through intensified interest, energy, or participation in a cultural form. This same metaphor of death or near-death makes the term objectionable to some indigenous activists who prefer to draw attention to ongoing vitality, but equally appropriate to others depending on historic and recent political conditions. ${ }^{12}$ Nevertheless, "revival" remains the preferred term among folklorists, who have historically promoted revivals, and who have produced a wave of studies on cultural and folkloric revivals since the 1980s. ${ }^{13}$

On the other hand, the study of "revitalization movements" falls solidly within the traditions of anthropology. Beginning in the 1940s, anthropologists documented cultural revitalization, particularly religious revitalization, among Native American communities. The term was explicitly introduced by Anthony Wallace, ${ }^{14}$ who understood cultural revitalization in psychological and cognitive terms. In his model, society ordinarily exists in a stable state, but when this stability is disrupted by various forms of stress, the society collectively experiences confusion, disorientation, and depression, until a charismatic leader emerges with a new vision which reorders the "mazeway" and returns stability. Wallace's model dominated studies of intensified religious activity throughout the world through the 1970s.

From the 1970s, however, studies that strictly adhere to Wallace's model have declined. At the same time, anthropologists have given greater attention to more secular manifestations of revitalization, such as tourism, festivals and performance, shifting the focus of the concept increasingly away from charisma, and towards the study of identity. ${ }^{15}$ In this shift, anthropological theory appears to have followed actual changes in social process. ${ }^{16}$ The widening of the concept

12 Marjorie Mandelstam Balzer, “The Tenacity of Ethnicity: A Siberian Saga in Global Perspective." Princeton, NJ: Princeton University Press, 1999, 3; Marjorie Mandelstam Balzer, "Healing Failed Faith? Contemporary Siberian Shamanism.” Anthropology and Humanism, 2001, (26) 2: 143.

13 Regina Bendix, In Search of Authenticity: The Formation of Folklore Studies. Madison, Wisc: University of Wisconsin Press, 1997, 209.

14 Anthony Wallace, "Revitalization Movements." American Anthropologist, 1956, 58(2): $264-$ 281.

15 Frank Manning, "Cup Match and Carnival: Secular Rites of Revitalization in Decolonizing, Tourist-Oriented Societies." In: Secular Ritual. Sally Falk Moore and Barbara. Myerhoff eds. Amsterdam: Van Gorcum, 1997.

16 Jeremy Boissevain ed., Revitalizing European Rituals. London: Routledge, 1992. 
of revitalization, however, beyond its application to phenomena that can be strictly considered "movements," has created additional slippage and ambiguity with the concept of revival. In a recent volume, Harkin ${ }^{17}$ argues for a renewal of Wallace's model of revitalization movement that would bring the study of both political and religious movements under a common framework, thus bringing cargo cults and nationalisms (among many other phenomena) into direct comparison. Most of the contributors, however, sidestep the problems posed by the existence of multiple definitions of revitalization, many of them only implicit that have appeared in the intervening decades.

Recent authors, who explicitly consider both terms, conclude - without adequate discussion - that revival and revitalization are essentially the same, and devote their efforts to refining formal typologies to rationalize the continued use of both terms. Ronstrom, ${ }^{18}$ for example, writes that "cultural revival" belongs to a family of related concepts, "coined to cover basically the same type of phenomena: revival, revitalization, recreation, reorientation, re-enacting (7),"and even "folklorism" and "fakelore." In short, all of these terms refer to discrete elements of culture that are more or less consciously embellished in identity projects. The task then, is to further classify particular examples. Ronstrom, for example, distinguishes between object-focused and process-focused studies of revival - in the first type, the focus is on a thing that is being revived (musical genre, for example), while in the second - the focus is much more likely to be on revival as part and parcel of a social movement. ${ }^{19}$ Alternatively, Boissevain ${ }^{20}$ provides a categorization based on distinguishing relations between the past and present, and proposes that seven terms be used to specify the nature of the new tradition. ${ }^{21}$ While approaches such as these allow that the revival or revitalization of particular traditions, or "tradition" in general, often accompany social movements, they do not further interrogate the relation of these phenomena with revitalization movements in the classic sense

17 Harkin, Reassessing Revitalization Movements...

18 Owe Ronstrom, “Revival Reconsidered." World of Music, 1996, 38(3): 5-20.

19 Ronstrom, Revival Reconsidered ..., 8-9; Burt Feintuch, "Revivals on the Edge: Northumberland and Cape Breton: A Keynote". Yearbook for Traditional Music, 2006, 38:1-17.

20 Jeremy Boissevain ed., Revitalizing European Rituals. London: Routledge, 1992.

21 Boissevain proposes the following terms: invention (for demonstrably new traditions), innovation (introduction of new elements, such as recorded music), revitalization (of something that never disappeared), revival/reanimation (of something that had been dormant), restoration/resurrection (of something that had been dead or forgotten), retraditionalization (restructuring and making more authentic), and folklorization (preservation and/or performance of elements out of context) (1992: 8-9). 
of the term. In the growing literature on folk and folkloric revivals, ${ }^{22}$ there is thus no clear precedent for discussing such a movement explicitly in terms of revitalization movements.

A subtler argument about the relationship between revival and revitalization is suggested by Balzer. ${ }^{23}$ In her formulation, revitalization movements are generated out of hope and desire for spiritual revival and holistic cultural integration. From this perspective, classic revitalization movements (i.e. religious cults led by charismatic leaders) are only one possible manifestation of hope and desire for spiritual revival/revitalization and cultural integration. A folkloric movement, such as Moldova's, might well be another avenue through which people attempt to reclaim a satisfying spiritual life and holistic cultural integration.

\section{Moldova's National and Folkloric Movements}

Moldova's folkloric movement emerged in concert with the national movement in the 1980s. As will become clearer below, the folkloric movement had an "object-focused" goal which involved the reform of amateur folkloric performance ensembles, so that the repertoires, costumes, and performance styles were "authentic" representations of local tradition. The movement was also process-focused on "rebirth" (i.e. "revival" or "revitalization", as described above). Because it emerged at the same time as Moldova's national movement and because the two movements were intertwined, even in the early 2000 s, the descriptions of the envisioned "rebirth" that I documented also mixed the political and the cultural. Rather, members of the folkloric movement tended to imagine the subversion of politics to culture; ideally, cultural rebirth would have produced a situation in which the state was organized and run in such a way that it served the development of local cultural traditions and beliefs, rather than the other way around. Because the two movements were intertwined, the folkloric movement never resolved fully the basic conflict between ethnic and national identity that was at the heart of the national movement, and which caused it to splinter into multiple political parties by the late 1990s. That is,

22 E.g. Max Peter Baumann, "Folk Music Revival: Concepts between Regression and Emancipation”. World of Music, 1996, 38(3): 71-86; Georgina Boyes, The Imagined Village: Culture, Ideology, and the English Folk Revival. Manchester: Manchester University Press, 1993; Marianne Bröcker, "Folk Dance Revival in Germany". World of Music, 1996, 38(3): 21-36; Robert Cantwell, When We Were Good: The Folk Revival. Cambridge, Mass.: Harvard University Press, 1996; Carla De Sousa, "The Inventions of Alte: The Most Traditional Village in Algarve, Portugal”. Folk, 2000, 42:101-118; Niall MacKinnon, The British Folk Scene: Musical Performance and Social Identity. Maidenhead. Berkshire: Open University Press, 1994.

23 Balzer, Healing Failed Faith? ..., 135. 
although the national movement soon became one for ethnic Moldovans and the central concern became their Romanian identity, in the very early days of the movement leaders of other minorities had joined with the ethnic Moldovans in a common movement for Moldova's sovereignty. In contrast to the national movement which narrowed its focus to ethnic Romanians and thus collapsed as a political force, the folkloric movement preserved the early alliance between ethnic Moldovans and minorities with a focus on the shared experiences of rural life and the positive valuation of (almost) all ethnic cultures, though not without significant tension.

There are a number of features which distinguish Moldova's folkloric movement from folkloric movements elsewhere. First is the primarily professional character of the movement. Public concerts gained the attention of the broader public, but when I conducted interviews in the early 2000s, people who recognized their own involvement, or that of others, in the movement where overwhelming professionals employed in some field of art, culture, or scholarship. The folkloric movement, however, encompassed a broad swath of professional intellectuals and culture workers. Professional folklorists, ethnographers, and musicians, along with school teachers, historians, musicians, dancers, visual artists, writers and journalists, folk artists, and personnel from within the Ministry of Culture and county-level departments of culture mobilized to promote authentic folklore.

The second distinguishing feature of Moldova's folkloric movement is that leadership appears to have been diffuse. People I interviewed were aware of participating in a "movement", they recognized fellow participants, and they sensed both moments of success and declining interest. However, they rarely provided a genealogy of the movement, or identified clear leaders. This distinguishes Moldova's movement from others, such as the táncház movement in Hungary, ${ }^{24}$ where participants self-consciously tracked the emergence and development of their activities.

To the degree that the movement had a leader, most of my informants acknowledge the guiding influence of Andrei Tamazlâcaru who organized the ethno-folkloric (etno-folcloric) music ensemble, Tălăncuţa. The ensemble set the standards for authentic performance, described below, with its emphasis on direct collection of repertoire materials through fieldwork, careful reproduction on stage, and costumes that accurately copy materials, styles, and decorative motifs worn before the second World War. Tamazlâcaru was a professor in the Folklore Department at the state Art Institute in Chişinău, who gradually

${ }^{24}$ Laszlo Kurti, The Remote Borderland: Transylvania in the Hungarian Imagination. Albany: State University of New York Press, 2001. 
organized the ensemble from an extracurricular student club. Key members of the ensemble joined from approximately 1980-1984, and in the early 2000s the ensemble consisted of seventeen members. Tamazlâcaru took Tălăncuța with him, when he left the university to work at the Musicians' Union in the early 1990 s, and the group became a "state ensemble" with all the associated benefits and detractions of funding and command performances.

Throughout the 1980s, each of the ensemble's members created at least one additional ethno-folkloric ensemble for children or adolescents in kindergartens, schools, culture houses, or pioneer houses. Andrei Tamazlâcaru's ${ }^{25}$ work in ethnopedagy also provided the ideological shaping for their work in spreading authentic folklore to children and adolescents. Tamazlâcaru is, indeed, an important figure in the movement - particularly in his frequent roles as festival organizer and jury member. Yet he does not expressly claim leadership for the movement, and the twenty-odd individuals who have formed the core ensemble over time, also present the development of their careers as accidental, effectively denying that they ever planned to lead a movement, as such, although they speak broadly of wanting "to do something for the country, for the people."

A third feature of Moldova's folkloric movement that bears mentioning is that informants rarely mentioned the existence of external influences on the movement's formation or activities. Instead, participants stressed the autochthonous development of their movement. Such a depiction of the movement as originating entirely from local concerns is significant because Moldova's folkloric movement was only one among many developing throughout Europe and North America after World War II. Some of the European and American movements are known to have developed through rich patterns of exchange with others. ${ }^{26}$ Moreover, there were several folkloric movements in Europe's socialist east. Those in Hungary, Lithuania, and Russia began in the early 1970s, ${ }^{27}$ and the national movement in Latvia dramatically

25 Andrei Tamazlâcaru, Tənyueıe, mənymeı (Tăpușele, tăpușele). Chișinău, Moldova: Literatura artistică, 1986.

26 E.g. Georgina Boyes, The Imagined Village: Culture, Ideology, and the English Folk Revival. Manchester: Manchester University Press, 1993; Marianne Bröcker, Folk Dance Revival in Germany. World of Music, 1996, 38(3): 21-36; Robert Cantwell, When We Were Good: The Folk Revival. Cambridge, Mass.: Harvard University Press, 1996; Niall MacKinnon, The British Folk Scene: Musical Performance and Social Identity. Maidenhead, Berkshire: Open University Press, 1994.

27 Laszlo Kurti, The Remote Borderland: Transylvania in the Hungarian Imagination. Albany: State University of New York Press, 2001; Vytis Ciubrinskas, "Identity and the Revival of Tradition in Lithuania: An Insider's View”. Folk. 2000, 42: 19-40; Theodore Levin, Dmitri Pokrovsky 
transformed the republic's mass folksong festival in 1990 by inviting participants from abroad ${ }^{28}$. Moldova's folkloric movement developed nearly a decade later than those in Hungary, Lithuania, and Russia, and probably was influenced by them. At the very least, both professional and amateur ensembles circulated between the performance festivals hosted by the various socialist countries; more specifically, training materials within the Soviet republics had a common inspiration (and eventually enemy) in Russian-produced materials.

If folkloric movements from the socialist east are compared, then the features of Moldova's movement make it more like Russia's movement (and Central Asia ones, which I don't review here) than to any of the others. In contrast to the movements in Hungary and Lithuania, for example, which claimed substantial connections to emerging youth cultures, the movements in both Moldova and Russia really expanded through institutionally organized ensembles that collected and performed "authentic" repertoires. Nevertheless, members of Moldova's folkloric movement never ascribe knowledge of, exposure to, inspiration from, or admiration of similar activities occurring within Russia.

Rather, the "movement" was experienced as a broad-based and locally specific effort to educate the general population about "authentic" folklore, inspire appreciation and pride in local aesthetic codes, and reinvigorate traditional crafts. As within the national movement, members of the folkloric movement were, and still are, divided in opinion on whether Romanian folklore (from Romania) can be performed and presented as authentically Moldovan, and on whether Moldova's ethnic minorities have their own distinct traditions. Publicly, however, the movement articulated and institutionalized a set of standards that insisted on rigorous documentation of folklore at the local level. The result is that the folkloric festivals and concerts created by the movement showcase Moldova as a "nation of villages," rather than as an ethnically-defined nation. Yet as the growing sense of failure among participants indicates, they also hoped their work would produce broader social change.

and the Russian Folk Music Revival Movement. In: Mark Slobin, ed. Retuning Culture: Musical Changes in Central and Eastern Europe. Durham and London: Duke University Press, 1996, 1436; Laura Olson, Performing Russia: Folk Revival and Russian Identity. New York and London: Routledge Curzon, 2004.

28 Inta Gale Carpenter, “Festival as Reconciliation: Latvian Exile Homecoming in 1990.” Journal of Folklore Research, 1996, 33(2): 93-124. 


\section{Object-Focused Revival: The Reform of Soviet Performance}

Moldova's folkloric movement did not introduce folkloric performance to a wide public audiences, so much as reform it from within existing institutional structures. During the preceding decades of Soviet rule, over 3,000 amateur ensembles had been organized through the Soviet culture system for both children and adults. ${ }^{29}$ These groups were classified into nine different genres, representing two kinds of dance, four kinds of music, and three kinds of theater: popular dance groups, popular music orchestras, fanfare (marching or brass bands), choirs, popular theater, youth theater, puppet theater, ballroom dancing, and "light" (pop-rock) music ensembles. All of the popular (Romanian) (called narodnyi in Russian) ensembles, with the occasional exception of theater, as well as fanfare and some choirs performed folk materials. That is, these ensembles which were also the most numerous - performed music, dance, or combinations of both, that were based on traditional Moldovan forms, but which had been substantially re-worked and stylized for performance.

Amateur folkloric performance groups were established throughout Moldova's territory by both Romanian and Soviet authorities during the interwar period, along with culture hearths and houses. After 1941, additional culture houses, and performance groups along with them, were systematically established in almost every village as the Soviet culture system matured. By the early 2000s, Moldova still had 1,245 operational culture houses, but inadequate maintenance and repair has continued to result in diminishing activities and the widespread closure of culture houses. ${ }^{30}$

The expansion of nationally-inflected amateur performance groups reflected Soviet cultural policy. On the one hand, opportunities for amateur performance for children and adults provided organized leisure, which was argued to be a necessary component for building a healthy and productive working class. ${ }^{31}$ At the same time, national forms were considered especially appropriate for the Soviet republics and especially their rural areas (as opposed to Russian metropolitan centers) because they had the double advantage of fostering national culture and being relatively cheap (e.g. compared to classical

29 The figure is an estimate of current ensembles from the director for the National Center for Folk Creation in 2001; Ministry of Culture officials were unable to produce official statistics for the past.

30 European Cultural Foundation and Soros Foundation-Moldova, Viziuni de viitor: Politica culturală a Republicii Moldova de la schimbări la viabilitate. Visions on cultural policy of Moldova: From changes to sustainability. Chișinău: Editura Arc, 2009, 133.

31 A.A. Zvorykin, Cultural Policy in the Union of Soviet Socialist Republics. Paris: UNESCO, 1970, 48. 
orchestras). ${ }^{32}$ Yet the Soviet cultural system also had the disadvantage of promoting ethnic inequality, as individuals from ethnic minorities were rarely encouraged to specialize in European high-art forms of music or dance, such as ballet, opera, or symphonic orchestras. ${ }^{33}$

When I conducted my research in Moldova in the early 2000s, people generally accepted the Soviet tiered-system. They did believe that performers should specialize in genres appropriate to their "own" ethnic tradition, but at the same time, European art-forms were not considered to be out of the reach of any ethnic group in Moldova. Instead, I was told that the folk traditions were foundational to the European forms; just as the high-art forms developed from folk forms in the preceding centuries, so it was appropriate for young children to learn folk genres, and only later (when their bodies were stronger) to specialize in the "higher" genres. The folk genres, moreover, were said to promote positive effects on the health, posture, social values, and individual personal development of young children.

In Moldova, the impetus for reform of Soviet performance genres and styles came from a growing critique of the over-stylization and ideologization of Soviet folklore. Generally speaking, it is not possible to transfer folk performance styles from "field" to "stage" without some change and stylization. Moving dance to the stage, for example, almost always creates a sharp distinction between audience and performers that had not existed before. Yet as Shay ${ }^{34}$ demonstrates, Soviet folk dance ensembles occupied the far extreme on a continuum of stylization, led by the aesthetic principles of the Moisseyev ensemble. As elsewhere in the Soviet Union, folk performance in Moldova was rarely allowed to be "pure artistic expression," but was harnessed to other ideological goals. For the participants in Moldova's folkloric movement, the ideological goals had become too overbearing and the stylization so extreme that they were no longer acceptable representations of the "field" traditions.

Part of the folkloric movement's aim was thus very-much "object-oriented" as a technical reform of costumes, repertoires, and staging. The highly-stylized Soviet folk performances required choreographed music and dance, which was produced by professionals who often did not consult archives or field materials - had to go. The employment of conventional motifs, in costumes and music,

32 Mary Doi, Gesture, Gender, Nation: Dance and Social Change in Uzbekistan. Westport, Conn: Bergin and Garvey, 2002; Swift, Mary Grace, The Art of the Dance in the U.S.S.R. Notre Dame, Ind.: Notre Dame Press, 1968.

33 Doi, Gesture, Gender, Nation ...

34 Anthony Shay, Choreographic Politics: State Folk Dance Companies, Representation and Power. Middletown, Conn.: Wesleyan University Press, 2002. 
to signal "Moldovan" and other ethnic identities - had to go. Performances that were driven by narrative rather than field-based contexts of performance (e.g. ritual) - had to go. Instead, performances should replicate traditional performance contexts as closely as possible

\section{From Object to Process: The Folkloric Movement as a Vehicle for Revival and Revitalization}

The technical objections that the folkloric movement made to Soviet performances of folklore were connected to three other objections that enabled movement members to perceive a wider scope to their activities. The related objections were: 1) a moral critique based on the costumes used in popular performances; 2) a complaint against how ethnic relations were represented; and 3) a political critique against the centralized production of local culture under the auspices of federal institutions in Moscow. To summarize these objections briefly: the moral critique of mass-produced costumes noticed that they failed to follow traditional aesthetics and the traditional requirements of modesty; colors were too bright, patterns too big, and short circle skirts lifted well above girls' knees when they danced. As for ethnic relations, the folkloric movement objected to amateur performances which conveyed messages of inter-ethnic friendship and brotherhood; they especially objected to the representation of a hierarchy of cultural superiority in such performances, when ethnic Russians and Ukrainians were shown to "lead" Moldovans in the given storyline. The final objection had to do with the control of local culture from Moscow: the textbooks and manuals that contained newly choreographed pieces were prepared and distributed by Moldova's Ministry of Culture, costumes were also mass-produced and dispatched by a central authority, ${ }^{35}$ and experts were dispatched from the capital to instruct local ensemble directors in implementation.

Because these perceived problem areas were linked to the first set of technical objections, the folkloric movement combined object- and processorientations in its efforts at cultural revival. As a process-oriented vehicle for

35 Folkloric ensembles have a longer history in Moldova than most participants in the Folkloric Movement like to admit. The Romanian government also established a system of "cultural hearths" throughout Bessarabian villages during the inter-war period. Folkloric ensembles, among other activities, were organized through these hearths, as well as through schools, and also received guidelines, textbooks, manuals, and costume patterns from the national ministries in Bucharest. These earlier ensembles also affected the "authenticity" of local traditions, and tended to "Romanianize" them (Buzilă n.d., Irina Livezeanu, Cultural Politics in Greater Romania: Regionalism, Nation Building, and Ethnic Struggle, 1918-1930. Ithaca: Cornell University Press, 1995). 
revival, the folkloric movement sought to use folkloric performance (and the associated processes of field-based documentation and collection) to renew local traditions, aesthetics, values, and moral codes; to reinvigorate the engagement of local communities with their own traditions; and - ultimately - to revive national identity. In their professional capacities, members of the movement collected authentic folklore from villagers, encouraged ensemble directors to do the same, initiated festivals and competitions designed to judge authenticity, and produced radio and television programs highlighting "authentic" local folklore. Through these activities, they aspired to restore knowledge of and value to local performance styles and all that was associated with them. They believed too, that undoing the Soviet effects on folklore, would undo analogous effects of Soviet rule on society.

\section{Failure and Misdiagnosed Success}

By the early 2000s, the folkloric movement seemed successful to me. Folkloric performance was highly visible - in a country of just four million people, as many as 2,000 amateur ensembles with folklorically-oriented repertoires existed, ${ }^{36}$ and more than twenty new festivals had been established. The folkloric movement had also succeeded in introducing a terminology to reference degrees of authenticity in ensemble performances; two new forms of ensemble - the folkloric (folkloric) and ethno-folkloric (etno-folcloric) ensemble - had come into being. Folkloric ensembles were considered "authentic" in contrast to the earlier popular/narodnyi ensembles, but they still performed a regionally-mixed repertoire. Ethno-folkloric ensembles, however, represented the ideal: these were village based ensembles that collected their own material from local villagers, and then faithfully reproduced it on stage. Many ensembles were in fact at intermediate points in this continuum of authenticity, and festival judges encouraged further "purification" of both repertoires and costumes.

So although "Soviet" style folklore continued to be performed, knowledge had spread widely about how to identify different degrees of authenticity. Indeed, many of the individuals I met outside of professional folklore circles argued over the authenticity of particular performances and groups; some still preferred the more dramatic presentation of the less authentic ensembles, and were prepared to argue their case.

Yet despite such successes, by 2001, members of the movement already sensed defeat, and by 2006, defeat felt complete, even as participants continued their efforts. Failure was located in decreased public interest and the reduced

36 Estimate based on 2001 figures from the National Center for Folk Creation and the Ministry of Culture. 
emotional appeal of folkloric performance; audience members no longer cried and performers sensed that they no longer produced, or tapped into, feelings of "unity" among people. In the mid-2000s, oameni de cultură also felt defeated by various political and social changes: poverty, high rates of migration, and the renewed power of the Communist Party left them feeling that their work was impossible, futile, and under-appreciated. Though folkloric forms continued to proliferate in festivals and performance, there was little hope for something as broad as cultural revival.

It is this situation which prompted the present essay. From a comparative perspective with other folkloric movements, and more generally with other forms of cultural revival, did Moldova's folkloric movement succeed or fail? The answer, theoretically speaking, is a little bit of both. The movement succeeded in its object-oriented goals, but - as comparison with other movements shows - it is this success that generates a feeling of failure in what concerns the movement's process-orientation.

The perception of failure described by members of the folkloric movement reveals the limits of revival, and in turn, the structural conditions under which local identity projects are taken. In a somewhat similar approach to investigating whether the charismatic Christian revivals that were reported as flourishing in the anthropological literature of the 1980s, had disappeared in reality, along with their disappearance from print, Robbins (2001), suggests that the very notion of a "movement" anticipates its own ending. As in the case of Moldova's folkloric movement, he finds that that religious revival among the Uropmin of Sanduan Province, New Guinea, has "ended" in the institution of a local church and leaders. Yet his fieldwork does not reveal disappointment - quite the contrary, the new church has in fact institutionalized "revival" as its specific form of religious experience. As in this example, the "failure" of Moldova's folkloric movement is more precisely a particular kind of ending for a revival movement, as internally reformed institutions embraced and promoted authentic folklore.

Joshua Fishman similarly interpreted the disappearance of ethnic revivals in the United States ${ }^{37}$ as a sign that they had succeeded in meeting their ostensible goals during the 1980s. In contrast to others who see this disappearance as a sign of failure, Fishman argues that the revivals accomplished their primary task of making "sidestream ethnicity" not only acceptable, but an expected component of American identity. Once it was expected that an "American" should also be "Irish," "Italian," "German," etc., the earlier festivals, parades,

37 Joshua Fishman et al., The Rise and Fall of the Ethnic Revival. Berlin, New York, Amsterdam: Mouton, 1985, 489-526. 
and community events focused on these ethnic heritages no longer held the same mass appeal they had when large numbers of individuals sought public affirmation of their ethnic heritage. From this perspective, it could be argued that as Moldova gained independence, Soviet ideology disappeared, and the Romanian language gained widespread acceptance as a language for public use - that the various demands that united people's support for "tradition" were met through other avenues. In this situation, folkloric performance per se was no longer needed beyond its institutional function as an amateur art form and participatory entertainment.

But what of the process-oriented goals in Moldova's folkloric movement - were they achieved? Unlike the American ethnic revivals which sought to re-claim the diverse ethnic heritages of America and its citizens as a matter of national history, but did not require anyone to dispense with shared modern American lifestyles and common American values, Moldova's folkloric movement sought something closer to a retraditionalization of cultural and social life. As a process-oriented movement, the folkloric movement urges Moldova's citizens, and especially rural villagers, to undertake a broader retraditionalization of their aesthetic and cultural lives. During collecting expeditions, for example, folklorists, ethnographers, and performers regularly advise villagers on the superior aesthetics of locally hand-woven carpets, emphasizing the aesthetic value and beneficial psychological effects of the natural dyes and abstract and geometric figures found in the oldest carpets. They also encourage villagers to reinstate older dancing styles during public dances and abandon modern disco styles, to dance outside during daylight hours, and to wear traditional clothing while dancing. Visiting ethnographers and folklorists sometimes even encourage the extension of local traditions to political models, engaging in the process of locating "alternatives" to the models of democracy and multiculturalism being presented from "outside" Moldova's borders.

Indeed, for the most part, this broader reinvigoration of local aesthetics, traditional values, and "native" models for political behavior and collective action has failed to occur. Villagers desire modern lives, and many now embrace the results of cultural mixing that occurred during the Soviet period. From such value stances, even villagers who know and value local traditions (e.g. school teachers) may resist the personal implications of the folkloric movement's imperatives: if a carpet with large, bright red and pink flowers makes a woman happy, why should she replace it with one in a geometric pattern colored with natural dyes? I recorded such arguments frequently as I accompanied others on collecting expeditions. 
Importantly, it is easy to understand the disappointments felt by members of the folkloric movement over the process-oriented failure. It is not hard to imagine that the movement's aims of re-traditionalizing social and cultural life would have had sympathy among large swathes of the country's citizenry, both urban and rural. After all, complaints are common about dominant trends in personal and moral comportment and public aesthetics:

the revealing clothing of young women; very public displays of affection by young couples; poor manners and rude social behavior, especially accompanied by the misuse of socially-coded linguistic forms; public drunkenness; loud and unmelodic music in the market, public events, and ritual occasions; etc., etc. Nor is it hard to imagine that once faced with the restitution of private agricultural land, that Moldova's countryside might have experienced retraditionalization in both material and social terms. For example, rural citizens might well have reinvigorated traditional forms of social organization (e.g. work parties), to accomplish necessary agricultural work in conditions of cash shortage. After all, such strategies were known to villagers from personal experience (through the late-1960s); and venerated by folkloric ensembles that indeed collect and perform endless variations of clacă and şezătoare. Even the legislation concerning the privatization of collective farms seemed to support retraditionalization by awarding combinations of arable land, orchards, and vineyards that would enable each household to produce fully its necessities without engaging in specialization for the market. From my view, policies of land redistribution sought to create the same kind of peasant household portrayed by folkloric ensembles. ${ }^{38}$

Yet, such retraditionalization has not occurred, and much evidence points in a contrary direction. Few land holders work their own land, preferring to rent it back to "leaders" who frequently pay them in kind with wheat and oil. Villagers who do work their own land eschew reciprocal forms of labor, preferring to hire laborers for cash, or wine. Cash is fed into the budgets of village households particularly through high rates of migration, especially by the female heads of households - a trend that doubly diverges from the traditional model of the cohesive family and actual historical patterns of male labor migration. And, despite demonstrative declarations that we "do everything ourselves", village households are far from being "self-sufficient" in any commonly understood sense of the term. ${ }^{39}$

38 Jennifer R. Cash, "What do Peasants Want? Equality and Differentiation in Post-Soviet Moldova," Martor: The Museum of the Romanian Peasant Anthropology Review, 2014, 19: 163-174.

39 Jennifer R. Cash, "How Much is Enough? Household Provisioning, Self-Sufficiency, and Social Status in Rural Moldova," in Stephen Gudeman and Chris Hann, eds., Oikos and Market: Explo- 


\section{No Retraditionalization, and yet, Persistent Identities}

In this final section, I turn to an assessment of several indicators that cultural identities in Moldova have been revitalized in recent decades, even though cultural and social life has not been retraditionalized. Traditionally, anthropologists have been reluctant to concede the defeat of culture. Instead, since the advent of the study of identity, and especially of ethnicity, anthropologists have preferred to seek out subtle aspects of culture - key symbols, narratives, values, and even the faintest but distinct sense of peoplehood - as evidence that diversity persists, and is even intensified, in the face of modernization, economic integration into national and global markets, large-scale cultural transformations, and other forms of trauma. A look at cultural and social identities in Moldova reveals that here too some aspects of culture matter more to people than others, and that ethnic identities can be maintained and strengthened even as many particular customs, beliefs, and behaviors are changed.

Accordingly, my research over the past fifteen years also documents the persistence of a number of important cultural elements, symbols and values. I have written about many of these, such as the "red thread" of hospitality and "seven years at home". ${ }^{40}$ So too, have I documented the importance of "doing everything” at home, such as making one's own wine and preserving fruits and vegetables, regardless of whether one actually purchases substantial quantities of food, or even some of the wine itself. ${ }^{41}$ Relatedly, I have described why it so important to have a public reputation as a gospodar or gospodină, and how numerous rituals are used to acquire and demonstrate this status. My research additionally documents the intensification of the ritual calendar, even as the diversity in how holidays are celebrated diminishes. ${ }^{42}$ Finally, I have shown how elements of religious practice and belief are expanding rapidly into everyday life, producing a combined religious and cultural revival, which involves even those who believe little of official Orthodox Christianity and are skeptical of the moral conduct of priests and Church. For example, as increasing numbers of people (with widely varying degrees of religious belief or adherence to Church precepts) in Moldova participate in popular (not official) religious practices,

rations in Self-Sufficiency after Socialism. New York: Berghahn, 2015, 47-76.

40 Jennifer R. Cash, "Performing Hospitality in Moldova: Ambiguous, Alternative, and Undeveloped Models of National Identity." History and Anthropology, 2013, 24(1): 56-77.

${ }^{41}$ Jennifer R. Cash, "Economy as Ritual: The Problems of Paying in Wine," in Stephen Gudeman and Chris Hann, eds., Economy and Ritual: Studies of Postsocialist Transformations. New York: Berghahn, 2015, 31-51.

42 Jennifer R. Cash, "Capitalism, Nationalism, and Religious Revival: Transformations of the Ritual Cycle in Postsocialist Moldova." Anthropology of East Europe Review, 2011, 29 (2): 181-20. 
such as rituals of remembering the dead, bread given as pomană circulates through numerous kitchens, tables, bellies, and - by coincidence - minds and hearts. ${ }^{43}$

For all these reasons, I hesitate to join my voice with that of my earliest informants. Perhaps, the folkloric movement and cultural revival in Moldova have not really failed. Social and cultural practices are perhaps not as robustly re-traditionalized as they might have been, or might still be, but that is relatively unimportant when Moldova is again compared against other places.

For example, based on research in Siberia, the anthropologist Marjorie Balzer has emphasized that it is rare that any revitalization movement to match a theoretical model, and this includes being able to determine when it has in fact ended. ${ }^{44}$ Balzer studied the dramatic late and post-Soviet revitalization movements in Siberia, and documented that highly charismatic shaman leaders had receded from the center of public attention by the late 1990s. Although this might well signal a movement's end from existing theoretical models, she herself was not sure that it should be taken as such. As she pointed out, the shamans themselves were in mid-career; it was not clear what they would do next in their personal or professional lives, and thus it was "premature to artificially slap labels of "new religion," "cult," "fraud" or "aborted reform movement" on them (145)." As she concluded, it is less important to match movements with models and determine their levels of success and failure, and more important to see how they make particularly visible the particular social and cultural features of a community that is undergoing revitalization. In other words, revival and revitalization everywhere draw attention to the various cultural values, beliefs, and behaviors that a community might want to retain, embellish, and use to define themselves. In the process of revival, some of these possibilities will be abandoned or put away for another generation to re-discover and embrace, while others will be embraced in the present. Where identity persists, revival is ongoing, though it appears and re-appears in various forms; folkloric movements are only one such vehicle.

43 Jennifer R. Cash, "Charity or Remembrance? Practices of Pomană in Rural Moldova”. Occasional Paper, Max Planck Institute for Social Anthropology, Halle, 2013.

44 Balzer, Healing Failed Faith? ..., 134-149. 


\section{Rezumat}

Cuvinte cheie: Republica Moldova, identitiate, renaştere culturală

Timp de aproape trei sferturi de veac, antropologii, de rând cu folcloriștii, sociologii şi alți cercetători, au documentat în mod sistematic multiplele procese de renaştere și revitalizare culturală. Ei au acumulat un bogat corpus de date și dovezi care depun mărturie privind flexibilitatea și caracterul durabil și recurent al fenomenelor culturale. Această concentrare pe proiectele reușite de renaştere culturală a generat o literatură bogată și extinsă, care există cumva în paralel, dar și în mod complementar, față de atenția crescândă privind identitatea și etnicitatea, teme care au devenit preocupări de bază pentru toate științele sociale. În paginile acestui articol, eu fac referință la această literatură, pe care mă bazez pentru a analiza limitele renașterii culturale din Republica Moldova, în perioada post-sovietică. Analiza mea se axează, în primul rând, pe mișcarea folclorică din Moldova, care constituie subiectul cercetării mele doctorale și al primei mele cărți. În cadrul acestui câmp analitic mai larg, există câteva întrebări la care încerc să răspund, şi anume: cine inițiază şi se ocupă de munca asociată renașterii culturale? Care sunt scopurile acestor oameni? Care sunt metodele folosite de ei? Și, în fine, indiferent de faptul dacă reușesc sau eșuează, care sunt condițiile care fac posibil acest proiect? Deși eu pun aceste întrebări, referindu-mă, în mod special, la cazul Moldovei post-sovietice, ele pot fi aplicate multor comunități la nivel global. Aceste întrebări ne pot ajuta să avansăm în înțelegerea modului, în care identitățile colective se creează, se negociază și se modifică de-a lungul timpului. 